\title{
Progress in endoscopic treatment of hemorrhoids
}

\author{
Wenzhuang Ma ${ }^{1}$, Jintao Guo ${ }^{1}$, Fan Yang ${ }^{1}$, Christoph F. Dietrich ${ }^{2}$, Siyu Sun ${ }^{1}$ \\ 'Department of Gastroenterology, Shengjing Hospital of China Medical University, Shenyang, Liaoning Province, China; \\ ${ }^{2}$ General Medical Department (DAIM), Kliniken Hirslanden Beau Site, Salem und Permanence, Bern, Switzerland
}

\section{ABSTRACT}

Hemorrhoids are one of the most common diseases of the anorectal region. Previously, treatment for hemorrhoids included conservative treatment, outpatient treatment, and surgical treatment. The development of flexible reversible endoscopes has provided precise controllability and imaging, enabling further improvement and development of various endoscopic techniques to treat hemorrhoids. This article discusses several of these endoscopic techniques: rubber band ligation, sclerotherapy, and electrocoagulation. The development, efficacy, and advantages of these treatments are summarized and evaluated. It is expected that going forward, endoscopic technology will be further applied in clinical practice and may become the first-line method for the treatment of hemorrhoids.

Key words: endoscopic treatment, hemorrhoids, rubber band ligation, sclerotherapy, electrocoagulation

\section{INTRODUCTION}

Hemorrhoids, one of the most common anorectal diseases, can occur at any age and to any gender, and are reported to occur in more than half of the population over 50 years of age. ${ }^{[1]}$ The true incidence of hemorrhoids is difficult to estimate since many patients are reluctant to seek medical advice for various personal, cultural, and socioeconomic reasons. ${ }^{[2,3]}$ The etiology of hemorrhoids is controversial, but the current widely accepted theory is that they are caused by abnormal expansion and distortion of blood vessels and destructive changes in the anal cushions supporting the connective tissue. ${ }^{[4,5]}$

Hemorrhoids can be classified as internal, external, or mixed. Internal hemorrhoids are further divided into 4 grades according to severity (Figure 1): ${ }^{[6]}$

Grade I: blood in the stool during defecation, without symptoms of hemorrhoid prolapse;

Grade II: blood in the stool during defecation, with prolapse of the hemorrhoid that recovers after defecation;
Grade III: blood in the stool during defecation, with prolapse of the hemorrhoidal nucleus that does not recover after defecation, but can be manually replaced; and

Grade IV: blood in the stool during defecation with larger blood volume. The hemorrhoidal nucleus prolapses outside the anus and cannot be manually repositioned.

Hemorrhoid treatments include conservative, outpatient, and surgical methods. ${ }^{[7]}$ Conservative treatment options include adequate fluid and fiber intake, medication and lifestyle changes, especially including changes in bowel habits. ${ }^{[8]}$ If conservative treatment fails, patients with grade I-III internal hemorrhoids can choose from several outpatient treatments, including rubber band ligation, sclerotherapy, laser photocoagulation, bipolar thermocoagulation, cryotherapy, ultrasound-guided hemorrhoid artery ligation, and infrared therapy. ${ }^{[1,9,10]}$ Among these modalities, hemorrhoid banding is typically the most effective option, according to the American Society of Colon and Rectal Surgeons (ASCRS) latest clinical 
A

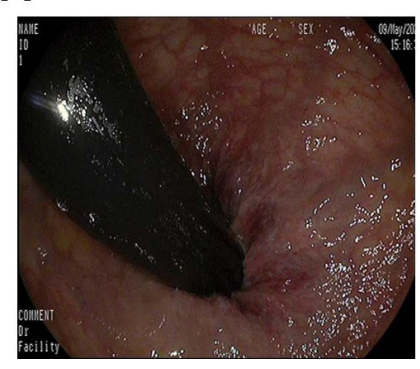

B

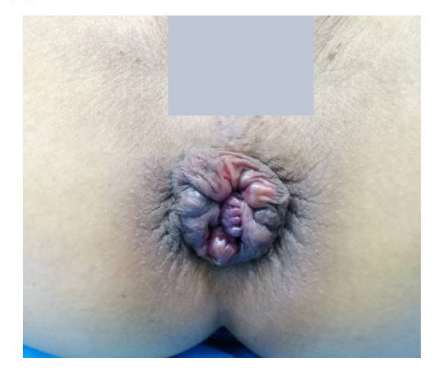

C

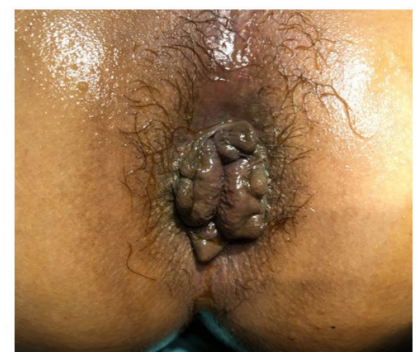

D

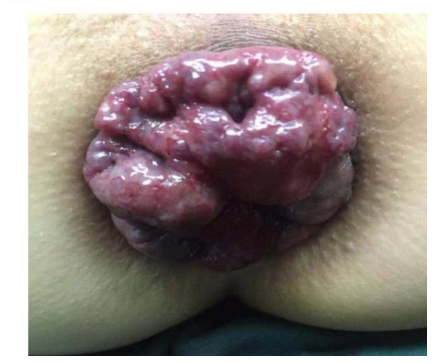

Figure 1: Classification of Internal hemorrhoids. A: Grade I; B: Grade II; C: Grade III; D: Grade IV.

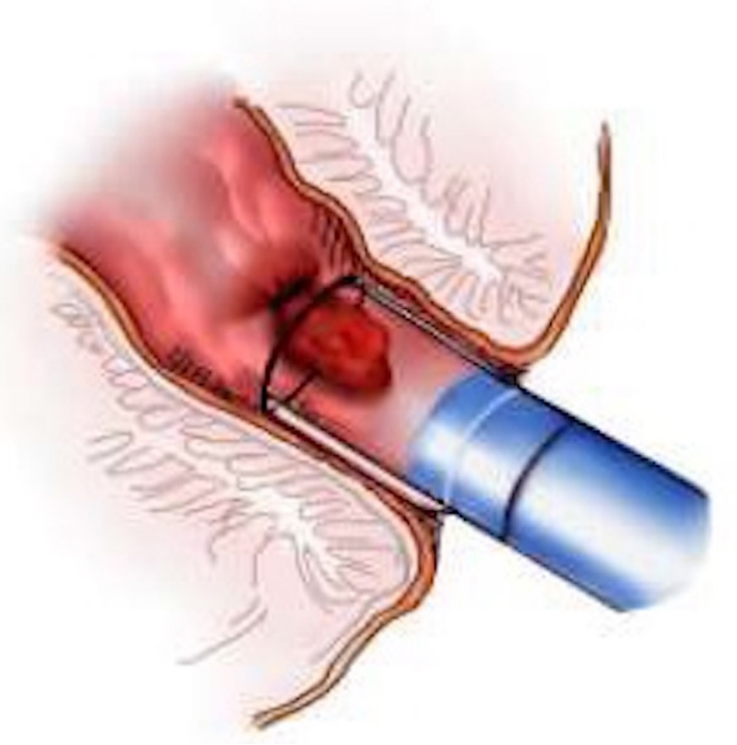

Figure 2: Diagrammatic drawing of how an endoscopic rubber band ligation is performed.

practice guidelines for the management of hemorrhoids ${ }^{[1]}$ and the guidelines for hemorrhoids by the Association of Colon and Rectal Surgeons of India. ${ }^{[12]}$ Surgical treatment such as hemorrhoidectomy, external hemorrhoid thrombectomy, and stapler hemorrhoidectomy is aimed at those patients who have failed outpatient treatment and have mixed or grade IV internal hemorrhoids. ${ }^{[13,14]}$

Most traditional outpatient treatments are performed by doctors via an anoscope. ${ }^{[15]}$ Due to the limited controllability of the equipment and the visual field, there is a risk of iatrogenic injury and complications. ${ }^{[16]}$ With the development of flexible endoscopes, ${ }^{[17]}$ the use of gastroscopes or flexible colonoscopy for the treatment of hemorrhoids provides controllability and high-quality imaging examinations that were not previously possible. ${ }^{[18,19]}$ This article reviews the development and efficacy of various endoscopic treatment techniques for hemorrhoids.

\section{ENDOSCOPIC TREATMENTS FOR HEMORRHOIDS}

\section{Endoscopic rubber band ligation}

Rubber band ligation (RBL) is the most used non-surgical treatment for grade II-III internal hemorrhoids, and was first introduced by Blaisdell in $1958^{[20]}$ and improved by Barron in 1963. ${ }^{[21]} \mathrm{RBL}$ is an effective, fast, simple, and economical technique. Recent research shows that RBL has a better cure rate and lower long-term recurrence rate than other technologies (sclerotherapy, far-infrared therapy, cryoablation, bipolar thermocoagulation, etc.) and is considered the best non-surgical therapeutic method. ${ }^{[22-25]}$ Ligation of hemorrhoidal tissue can lead to ischemic necrosis of the prolapsed mucosa, which in turn leads to scar fixation. ${ }^{[8,26,27]}$ This technique is easily tolerated by patients because the ligation is performed above the dentate line, where the tissue is insensitive to pain due to the lack of somatic nerves. ${ }^{[28]}$ It should be noted that RBL is contraindicated in patients with coagulation dysfunction, as there is limited evidence of the safety of the technique in this population. ${ }^{[6,26,29]}$

Endoscopic rubber band ligation (ERBL) (Figure 2) combines the classic ligation technology with the advantages of endoscopic examination for superior controllability and imaging. ${ }^{[30]}$ Doctors can use a gastroscope or colonoscope with a retroflexed position to suck and ligate the hemorrhoids above the anal dentate line in order to reduce postoperative pain. ${ }^{[9]}$ Further, multiple hemorrhoids can be ligated in a single operation. ${ }^{[25]}$ The operation procedure of ligation of internal hemorrhoids is shown in Figure 3. In general, a transparent plastic endoscopic ligation cap is attached to the top of the endoscope. Then, the dentate line is identified, and ligation is performed $2 \mathrm{~mm}$ to $5 \mathrm{~mm}$ above the dentate line. The hemorrhoid is suctioned into the cap with the tip of the endoscope in the anal canal, and a single elastic band is released. If further ligation is required, another rubber band is placed on the cap. 

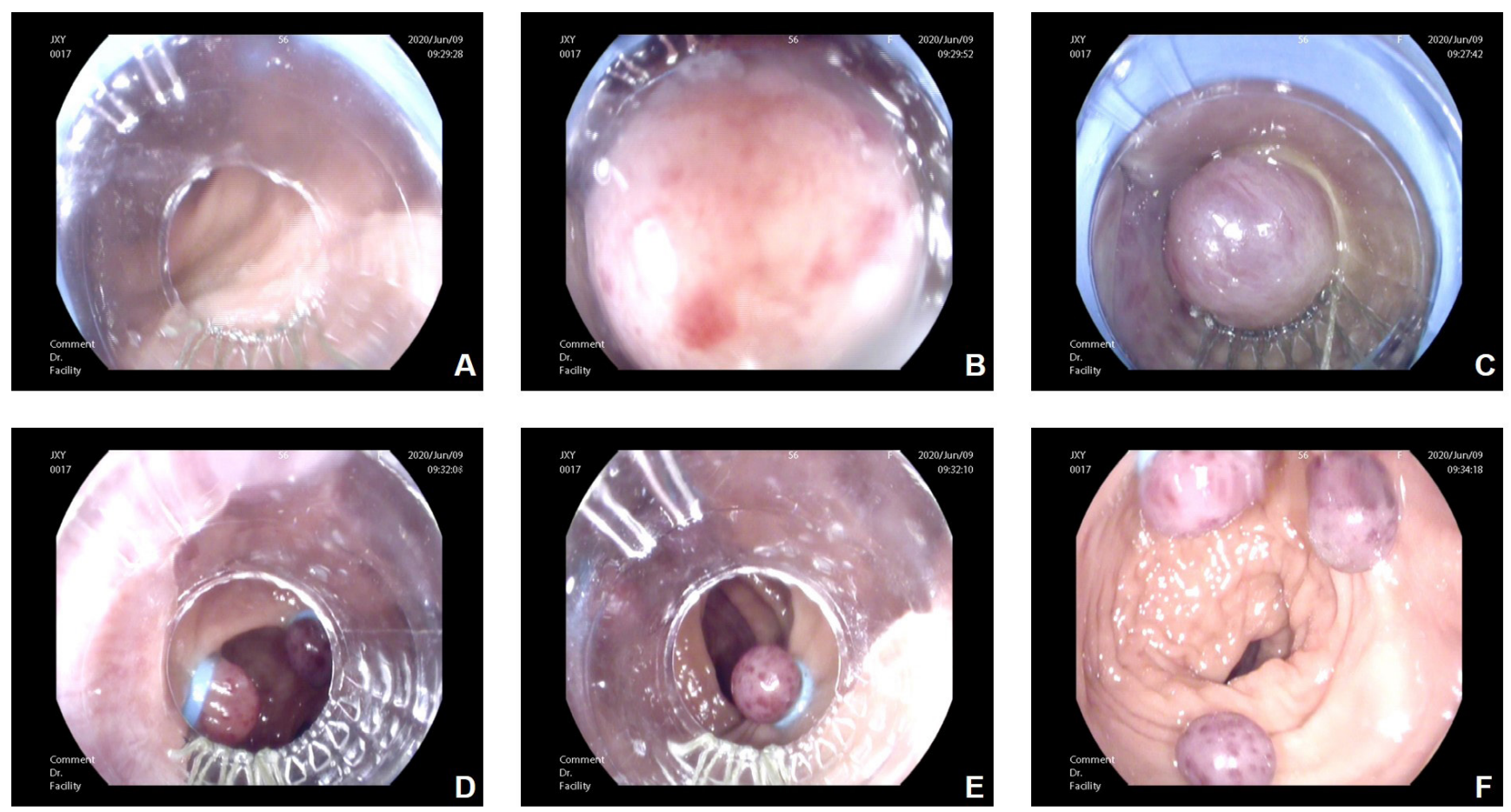

Figure 3: The operation procedure of ligation of internal hemorrhoids. B: A transparent plastic endoscopic ligation cap is attached to the top of the endoscope; Patients are treated if grade 2 or larger internal hemorrhoids were present; $C$ : The hemorrhoid is suctioned into the cap with the tip of the endoscope in the anal canal; D-E: A single elastic band is released; F: Further ligation is required, another rubber band is placed on the cap.

Trowers et al. ${ }^{[31]}$ first reported the use of ERBL to treat internal hemorrhoids in 1998. Among the 20 patients treated for grade II and III internal hemorrhoids, 19 patients $(95 \%)$ achieved a clinical downgrade of internal hemorrhoids, and symptoms were significantly relieved for 18 patients (90\%). Berkelhammer et al. ${ }^{[32]}$ used ERBL to treat 83 cases of hemorrhagic internal hemorrhoids by reversible endoscopy. The results showed that ERBL was effective in $80 \%$ of patients with grade II internal hemorrhoids. Further analysis showed that this method was more effective in treating patients with grade II internal hemorrhoids compared with grade III internal hemorrhoids. Mingyao Sun et al. ${ }^{[33,34]}$ designed the two largest clinical studies of ERBL treatment for grade II-IV internal hemorrhoids to date. The studies included 576 and 759 patients, respectively, and the longest follow-up period was 5 years. The conclusion of the studies was that ERBL is simple, safe, and effective, and has a low recurrence rate, which is worthy of clinical promotion. The latest cohort study ${ }^{[35]}$ of 116 patients designed by Henrique et al. found that ERBL was a feasible, safe, and effective method for treating symptomatic grade II-III internal hemorrhoids, but practitioners need to be alert for slight risk of early and late complications.

In addition, researchers have designed several controlled trials evaluating the efficacy of ERBL. Mingyao Sun et al. ${ }^{[36]}$ designed a randomized controlled clinical study involving 218 patients and compared the effects of different diameter rubber bands $(9 \mathrm{~mm}$ and $13 \mathrm{~mm})$. The results showed that both sizes were safe and effective, and there was no significant difference between the two in success rate and clinical remission rate. In addition, the recurrence rate after 1 year of follow-up was equivalent, and both methods were better than traditional RBL. However, a study published by Zaher Tarik et al. ${ }^{[37]}$ comparing ERBL or stapler hemorrhoidectomy for internal hemorrhoids in 26 patients with portal hypertension found that stapler hemorrhoidectomy was more effective for such patients.

These studies show that ERBL has certain advantages over traditional RBL in terms of efficacy, complication rate and recurrence rate, while the latter did show advantages compared with other conservative treatment with regards to efficacy, long-term successful rate, and less complication, ${ }^{[16,25]}$ but the conclusions regarding the indications for ERBL are still controversial. ${ }^{[38,39]} \mathrm{RBL}$ is more effective than sclerotherapy, and patients are unlikely to need follow-up treatment after the treatment. Though RBL is not as effective as hemorrhoidectomy, but it has fewer complications and less pain, thus can be used as a first-line treatment for hemorrhoids. We believe ERBL will become the first-line or preferred treatment method 
Ma et al.: Progress in endoscopic treatment of hemorrhoids

\begin{tabular}{|c|c|c|c|}
\hline Researcher and date & Subjects (N) & Disease & Conclusion \\
\hline $\begin{array}{l}\text { Trowers et al. } \\
1998^{[29]}\end{array}$ & 20 & $\begin{array}{l}\text { Grade II and III internal } \\
\text { hemorrhoids }\end{array}$ & $\begin{array}{l}95 \% \text { of patients achieved a clinical downgrade, and } 90 \% \text { had } \\
\text { significantly relieved symptoms without serious complications. }\end{array}$ \\
\hline $\begin{array}{l}\text { Berkelhammer et al. } \\
2002^{[30]}\end{array}$ & 83 & $\begin{array}{l}\text { Grade II and III internal } \\
\text { hemorrhoids }\end{array}$ & $\begin{array}{l}80 \% \text { of patients with grade II internal hemorrhoids had a significant } \\
\text { effect. This method had a better therapeutic effect in patients with } \\
\text { grade II internal hemorrhoids than in those with grade III hemorrhoids. } \\
\text { No long-term complications occurred. }\end{array}$ \\
\hline $\begin{array}{l}\text { Mingyao Sun et al. } \\
2003^{[32]}\end{array}$ & 218 & $\begin{array}{l}\text { Grade II to IV internal } \\
\text { hemorrhoids }\end{array}$ & $\begin{array}{l}\text { There was no significant difference between the } 9 \mathrm{~mm} \text { and } 13 \mathrm{~mm} \\
\text { rubber bands in terms of efficacy, incidence of complications, or } \\
\text { recurrence rate. }\end{array}$ \\
\hline $\begin{array}{l}\text { Mingyao Sun et al. } \\
2004^{[34]}\end{array}$ & 576 & $\begin{array}{l}\text { Grade II to IV internal } \\
\text { hemorrhoids }\end{array}$ & $\begin{array}{l}\text { The clinical remission rate was } 93.58 \% \text {, patient satisfaction was } \\
96.2 \% \text {, and the recurrence rate was only } 3.3 \% \text { after } 1 \text { year of follow- } \\
\text { up. }\end{array}$ \\
\hline $\begin{array}{l}\text { Fukuda, A et al. } \\
2004^{[36]}\end{array}$ & 82 & $\begin{array}{l}\text { Grade I to IV internal } \\
\text { hemorrhoids }\end{array}$ & $\begin{array}{l}\text { The clinical remission rate was } 100 \% \text {. Long-term response (mean } \\
\text { follow-up } 12 \text { months) was excellent for } 89 \% \text { of the patients, good for } \\
9 \% \text {, and poor for } 2 \% \text {. No major complication was noted. }\end{array}$ \\
\hline $\begin{array}{l}\text { Mingyao Sun et al. } \\
2011^{[31]}\end{array}$ & 759 & $\begin{array}{l}\text { Grade II to IV internal } \\
\text { hemorrhoids }\end{array}$ & $\begin{array}{l}\text { The clinical remission rate was } 93.6 \% \text { and the recurrence rate was } \\
16.9 \% \text { in the } 5 \text {-year follow-up. }\end{array}$ \\
\hline $\begin{array}{l}\text { Zaher Tarik et al. } \\
2011^{[35]}\end{array}$ & 26 & $\begin{array}{l}\text { Internal hemorrhoids } \\
\text { in patients with portal } \\
\text { hypertension }\end{array}$ & $\begin{array}{l}\text { Both ERBL and stapling can improve bleeding and prolapse, but stapler } \\
\text { hemorrhoidectomy is more effective than ERBL for such patients. }\end{array}$ \\
\hline $\begin{array}{l}\text { Henrique et al. } \\
2019^{[33]}\end{array}$ & 116 & $\begin{array}{l}\text { Grade II and III internal } \\
\text { hemorrhoids }\end{array}$ & $\begin{array}{l}\text { The incidence of short-term and long-term complications after } \\
\text { ERBL and the number of ligations have no obvious relationship with } \\
\text { treatment satisfaction. ERBL is a feasible, safe and efficient method for } \\
\text { symptomatic grade II-III internal hemorrhoids. }\end{array}$ \\
\hline
\end{tabular}

for hemorrhoids, but there are some important questions that need to be answered in ERBL that need further study. In particular, it has not yet been reported whether ERBL is suitable for external hemorrhoids. In addition, no reports have indicated how many rubber bands should be used to ligate different sizes of internal hemorrhoids and whether different sizes and numbers of bands will affect the outcome. Table 1 summarizes the main research reports on ERBL.

\section{Endoscopic sclerotherapy}

Sclerosants including ethanolamine oleate, ${ }^{[40]}$ quinine, ${ }^{[41]}$ hypertonic saline, ${ }^{[42]} \%$ phenol, ${ }^{[43]}$ An's Shaobei injection, Xiaozhiling injection, ${ }^{[4]}$ potassium aluminum sulfate and tannic acid, ${ }^{[45-48]}$ have been used for the sclerotherapy of grade I-II internal hemorrhoids. ASCRS recommends 5\% phenol dissolved in almond oil, vegetable oil or sodium tetradecyl sulfate in ASCRS Clinical Practice Guidelines for Hemorrhoid Management 2018. ${ }^{[11]}$ Sodium tetradecyl sulfate, a drug approved by the FDA for the treatment of varicose veins of lower extremities, makes the submucosal tissue fibrotic, and then fixes the hemorrhoidal tissue. ${ }^{[4]}$ The common method of sclerotherapy is to inject 0.5-2.0 $\mathrm{mL}$ of $1 \%$ sodium tetradecyl sulfate or $5 \%$ phenol under the mucosa at the top of the hemorrhoids. ${ }^{[26]}$ Traditionally, doctors must use an anoscope during sclerotherapy, which results in the dislocation of the sclerosing injection and may lead to potential complications, including pain, impotence, prostatitis, mucosal ulceration or necrosis, prostate abscess, and even abdominal abscess. These

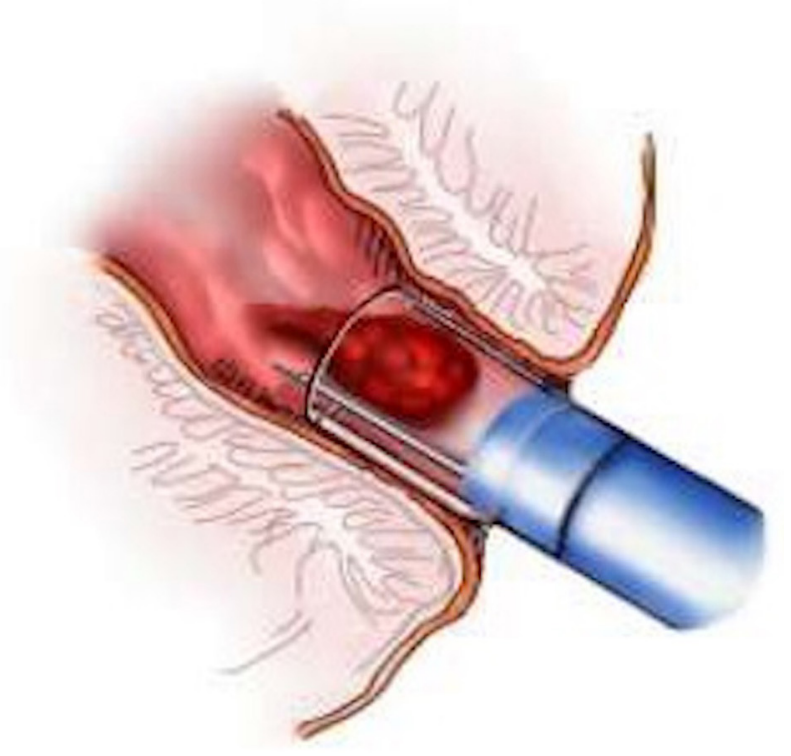

Figure 4: Diagrammatic drawing of how an endoscopic sclerotherapy is performed.

complications underscore the importance of precise injection with sclerosant. ${ }^{[1,40]}$

Ponsky et al. ${ }^{[50]}$ first attempted to use retrograde endoscopy to inject $23.4 \%$ hypertonic saline to treat internal hemorrhoids. The preliminary results of 19 symptomatic patients with grade I-III hemorrhoids showed that this technique was very effective in relieving bleeding. Further, 
Ma et al.: Progress in endoscopic treatment of hemorrhoids

\begin{tabular}{|c|c|c|c|c|}
\hline $\begin{array}{l}\text { Researcher and } \\
\text { date }\end{array}$ & Sclerosing agent & $\begin{array}{l}\text { Patients } \\
\text { (N) }\end{array}$ & Disease & Conclusion \\
\hline $\begin{array}{l}\text { Ponsky et al. } \\
1991^{[48]}\end{array}$ & $\begin{array}{l}23.4 \% \text { hypertonic } \\
\text { saline }\end{array}$ & 19 & $\begin{array}{l}\text { Grade I to III internal } \\
\text { hemorrhoids }\end{array}$ & $\begin{array}{l}\text { The clinical success rate was } 100 \% \text {; the method } \\
\text { relieved bleeding and prolapse without serious } \\
\text { complications. }\end{array}$ \\
\hline $\begin{array}{l}\text { Benin et al. } \\
2007^{[49]}\end{array}$ & $\begin{array}{l}\text { Sodium tetradecyl } \\
\text { sulfate }\end{array}$ & 250 & $\begin{array}{l}\text { Grade II to IV internal } \\
\text { hemorrhoids }\end{array}$ & $\begin{array}{l}\text { The clinical success rate was } 100 \% \text {; bleeding and } \\
\text { prolapse were resolved without serious complications. }\end{array}$ \\
\hline $\begin{array}{l}\text { Alatis et al. } \\
2009^{[50]}\end{array}$ & $\begin{array}{l}50 \% \text { hypertonic } \\
\text { glucose }\end{array}$ & 40 & $\begin{array}{l}\text { Grade I to IV internal } \\
\text { hemorrhoids }\end{array}$ & $\begin{array}{l}\text { The clinical success rate was } 100 \% \text {, and the follow-up } \\
\text { time was up to } 1 \text { year. Bleeding-grade prolapse was } \\
\text { significantly eased without serious complications. }\end{array}$ \\
\hline $\begin{array}{l}\text { Zhang Ting et al. } \\
2015^{[54]}\end{array}$ & Lauromacrogol & 30 & $\begin{array}{l}\text { Grade I to III internal } \\
\text { hemorrhoids }\end{array}$ & $\begin{array}{l}\text { The clinical success rate was } 100 \% \text {. One case had } \\
\text { a sudden emergency bleeding and then was cured. } \\
\text { The remaining cases had symptoms alleviated without } \\
\text { serious complications. }\end{array}$ \\
\hline $\begin{array}{l}\text { Tomiki eet al. } \\
2019^{[52]}\end{array}$ & $\begin{array}{l}\text { Potassium aluminum } \\
\text { sulfate and tannic acid }\end{array}$ & 81 & $\begin{array}{l}\text { Grade II and III internal } \\
\text { hemorrhoids }\end{array}$ & $\begin{array}{l}\text { The randomized controlled study showed that } \\
\text { endoscopic sclerotherapy is comparable to traditional } \\
\text { sclerotherapy in terms of efficacy, adverse events, and } \\
\text { recurrence. }\end{array}$ \\
\hline
\end{tabular}

it effectively relieved prolapse, was well tolerated, had high patient satisfaction, and few complications, with no serious complications. Benin et al. ${ }^{[51]}$ used endoscopic injection of sodium tetradecyl sulfate in 250 patients with grade II-IV internal hemorrhoids and confirmed the safety, effectiveness, and low complication rate of this method. Subsequently, additional studies have confirmed good therapeutic effects and low complication rates for endoscopic injection of $50 \%$ hypertonic glucose, ${ }^{[52]}$ aluminum potassium sulfate and tannic acid ${ }^{[53-55]}$ and other sclerosing treatments ${ }^{[5]}$ for internal hemorrhoids. Complications such as bleeding and transient pain were mainly caused by the injection or being located in an incorrect injection site. ${ }^{[5]}$

In order to improve the accuracy of endoscopic sclerotherapy and avoid the above complications, some researchers have used a cap-assisted endoscopic sclerotherapy (CAES) treatment of hemorrhoids. ${ }^{[5]}$ (Figure 3) Zhang et al. performed CAES for patients with grade I-III internal hemorrhoids. Postoperative observation and follow-up confirmed that CAES was effective and safer than ERBL. The sclerosant agent selected for the above-mentioned CAES study was lauromacrogol, which is particularly suitable for patients with I-II grade hemorrhoids with bleeding risk, and has the advantages of low treatment cost, safety and efficacy, easy operation, and high patient satisfaction. Whether other sclerosants can achieve the same effect using CAES has not been reported. Table 2 summarizes the main research on endoscopic sclerotherapy.

Sclerotherapy is a simple and safe palliative therapy, which only provides long-term relief in one-third of patients; in addition, the treatment of rectal prolapse by sclerotherapy is considered ineffective. However, we believe that with the development and application of new sclerosants (such as some traditional Chinese medicine), the prospect of endoscopic sclerotherapy is still very optimistic because it is safer than traditional treatments.

\section{Endoscopic coagulation}

The previous electrocoagulation system has low treatment efficacy and high recurrence rate and is gradually being replaced by other treatment methods. ${ }^{\left[{ }^{[7]}\right.}$ Kantsevoy SV et al..$^{[58]}$ developed a hemorrhoid energy therapy (HET ${ }^{\mathrm{TM}}$ ) bipolar electrocoagulation system that can electrocoagulate hemorrhoids under endoscopy. Kantsevoy applied this system to quickly complete electrocoagulation in 23 patients within an average of $37.3 \pm 8.6$ seconds. All the patients were followed up for one year without recurrence, which provided a new method for the endoscopic treatment of hemorrhoids. Subsequently, the same system was used by Crawshaw et al..$^{[59]}$ in a clinical trial containing 20 patients with grade I-II internal hemorrhoids, showing that the system was safe and had short-term efficacy. This therapy can be an effective alternative, especially for internal hemorrhoid patients with obvious pain after RBL. Mok et al. ${ }^{[00]}$ developed a similar endoscopic bipolar electrocoagulation device for the treatment of internal hemorrhoids, which also achieved good results. Wei ${ }^{[61]}$ showed safety and efficacy of endoscopic unipolar electrocoagulation in 100 cases of grade II-III internal hemorrhoids, and the recurrence rate at 3 years of followup was only $6 \%$. In addition, McLemore et al. ${ }^{\left[{ }^{[2]}\right]}$ developed an endoscopic infrared electrocoagulation system for the treatment of internal hemorrhoids. The symptoms of 55 patients were significantly improved, and no adverse events occurred. 
Endoscopic coagulation depends on the invention and application of new devices. In addition, the parameters of these devices need to be further revised and adjusted according to a large number of clinical trials, which also means that compared with the other two methods of endoscopic treatment of hemorrhoids, endoscopic coagulation requires more research effort, and the efficacy needs further evaluation.

\section{ADVANTAGES OF ENDOSCOPIC HEMORRHOID TREATMENT}

The various techniques of endoscopic hemorrhoid treatment combine the advantages of classic treatment via anoscope and endoscopy. First, the controllability of the endoscope and the quality of the imaging facilitate more accurate technical operations and avoidance of most iatrogenic risks. Secondly, ERBL, CASE, and endoscopic electrocoagulation are all similar to the existing endoscopic treatment techniques, and endoscopists can easily master the relevant technologies. Finally, the visualization of the anorectosigmoid region during endoscopy of the patient prior to treatment, identifies other colorectal diseases that may be contributing to the symptoms such as bleeding, especially colorectal neoplasia. ${ }^{[63-65]}$ In the United States, a cohort study based on blood in the stool reported that the incidence of diverticulosis, polyps or multiple polyps, mucosal abnormalities/colitis, tumors, and solitary ulcers were significantly increased in the patients undergoing endoscopy. ${ }^{[6]}$ In addition, anorectal diseases such as hemorrhoids are very common in patients with intestinal diseases. Studies have shown that about $10 \%$ of patients with inflammatory bowel disease (IBD) will develop hemorrhoids. Lesions of the colon and terminal ileum can be observed before endoscopic treatment if a full colonoscopy is undertaken, which will assist in the early diagnosis of IBD. ${ }^{[67]}$

\section{PROBLEMS IN THE RESEARCH OF RELATED TECHNOLOGIES FOR ENDOSCOPIC HEMORRHOID TREATMENT}

At present, there are only a few studies on endoscopic hemorrhoid treatment techniques, all of which are singlecenter studies with small sample sizes. Although the conclusions confirm that this technology has obvious advantages and application prospects, they cannot provide high-quality, evidence-based documentation. Further, most studies focus on endoscopic treatment of internal hemorrhoids, and there are few and controversial studies on the effects of endoscopic treatment of external and mixed hemorrhoids. In addition, although various methods for endoscopic treatment of hemorrhoids are reported to be safe and effective, the methods and treatments of each study are different. There is a lack of uniform operating standards, procedures, and use of equipment, so the conclusions of each study are somewhat variable. More importantly, there is no rigorous comparison to confirm the appropriate indications, as well as the advantages and disadvantages of the different methods. ${ }^{[6]]}$

Several studies have confirmed the unique advantages of endoscopic hemorrhoid treatment technology, but before further promotion to clinical practice, multi-center prospective studies involving larger numbers of patients and more rigorous design are needed to clarify the indications and contraindications of various technologies. Moreover, work is needed to clarify the standards and procedures of various operations to effectively assist in clinical decision-making. ${ }^{[69]}$ Although the present technology and methods have shown advantages and lower medical costs in the diagnosis and treatment of hemorrhoid-related anorectal diseases, further cost-effectiveness analysis is needed to achieve the best balance between medical effectiveness and costs.

\section{CONCLUSION}

Current research shows that compared with traditional treatment methods, endoscopic hemorrhoid treatment techniques can also effectively treat hemorrhoids in a minimally invasive fashion with shortened procedure time and reduces intraprocedural bleeding. In addition, the patient has less pain and recovers quickly, and other important colorectal pathologies can be detected at the same time. Because of the above advantages, various methods of endoscopic hemorrhoid treatment have been accepted by more and more by clinicians and patients; however, at present, the clinical application of endoscopic treatment of hemorrhoid has not been fully developed, only a few centers, as mentioned above, have carried out related researches and exploration. With the expansion of research and the continuous development of corresponding endoscopic instruments, ${ }^{[70]}$ endoscopic technology is likely to become a first-line or preferred treatment method for grade I-III internal hemorrhoids.

\section{Source of Foundation}

This work is supported by Youth Support Foundation of China Medical University (Grant No. QGZ2018058); Science and Technology Program of Shenyang (Grant No. 19-112-4-103); Outstanding Scientific Fund of Shengjing Hospital (Grant No. 201702); and Doctoral Scientific Research Foundation of Liaoning Province (Grant No. 2019-BS-276) 
Ma et al.: Progress in endoscopic treatment of hemorrhoids

\section{Conflict of Interest}

The authors declare no conflict of interests.

\section{REFERENCES}

1. Altomare DF, Giuratrabocchetta S. Conservative and surgical treatment of haemorrhoids. Nat Rev Gastroenterol Hepatol 2013; 10: 513-21.

2. Jacobs D. Clinical practice. Hemorrhoids. N Engl J Med 2014; 371: 944-51.

3. Nisar PJ, Scholefield JH. Managing haemorrhoids. BMJ 2003; 327: 847-51.

4. Mott T, Latimer K, Edwards C. Hemorrhoids: Diagnosis and Treatment Options. Am Fam Physician 2018; 97: 172-9.

5. Lohsiriwat V. Hemorrhoids: from basic pathophysiology to clinical management. World J Gastroenterol 2012; 18: 2009-17.

6. Idrees JJ, Clapp M, Brady JT, Stein SL, Reynolds HL, Steinhagen E. Evaluating the Accuracy of Hemorrhoids: Comparison Among Specialties and Symptoms. Dis Colon Rectum 2019; 62: 867-71.

7. Guttenplan M. The Evaluation and Office Management of Hemorrhoids for the Gastroenterologist. Curr Gastroenterol Rep 2017; 19: 30.

8. Lohsiriwat V. Treatment of hemorrhoids: A coloproctologist's view. World J Gastroenterol 2015; 21: 9245-52.

9. Cocorullo G, Tutino R, Falco N, Licari L, Orlando G, Fontana T, et al. The non-surgical management for hemorrhoidal disease. A systematic review. G Chir 2017; 38: 5-14.

10. Ray-Offor E, Amadi S. Hemorrhoidal disease: Predilection sites, pattern of presentation, and treatment. Ann Afr Med 2019; 18: 12-6.

11. Davis BR, Lee-Kong SA, Migaly J, Feingold DL, Steele SR. The American Society of Colon and Rectal Surgeons Clinical Practice Guidelines for the Management of Hemorrhoids. Dis Colon Rectum 2018; 61: 284-92.

12. Agarwal N, Singh K, Sheikh P, Mittal K, Mathai V, Kumar A. Executive Summary - The Association of Colon \& Rectal Surgeons of India (ACRSI) Practice Guidelines for the Management of Haemorrhoids-2016. Indian J Surg 2017; 79: 58-61.

13. van Iersel JJ, Formijne Jonkers HA, Verheijen PM, Draaisma WA, Consten EC, Broeders IA. High-grade hemorrhoids requiring surgical treatment are common after laparoscopic ventral mesh rectopexy. Tech Coloproctol 2016; 20: 235-42.

14. Gachabayov M, Angelos G, Bergamaschi R. THD Doppler: A Reliable Surgical Procedure to Treat Hemorrhoids. Surg Technol Int 2019; 34: 189-93.

15. Singal R, Gupta S, Dalal AK, Dalal U, Attri AK. An optimal painless treatment for early hemorrhoids; our experience in Government Medical College and Hospital. J Med Life 2013; 6: 302-6.

16. MacKay D. Hemorrhoids and varicose veins: a review of treatment options. Altern Med Rev. 2001; 6: 126-40.

17. Sahai AV. EUS is trending! Endosc Ultrasound 2018; 7: 353-5.

18. Bhatia V, Tajika M, Hijioka S. Radial-scanning flexible EUS of the anorectum and pelvis. Endosc Ultrasound 2019; 8: 288-97.

19. Dietrich CF, Bibby E, Jenssen C, Saftoiu A, Iglesias-Garcia J, Havre RF. EUS elastography: How to do it? Endosc Ultrasound 2018; 7: 20-8.

20. Blaisdell PC. Office ligation of internal hemorrhoids. Am J Surg 1958; 96: 401-4.

21. Barron J. Office ligation of internal hemorrhoids. Am J Surg 1963; 105 : 563-70.

22. Gallo G, Martellucci J, Pellino G, Ghiselli R, Infantino A, Pucciani F, et al. Consensus Statement of the Italian Society of Colorectal Surgery (SICCR): management and treatment of complete rectal prolapse. Tech Coloproctol 2018; 22: 919-31.

23. Gallo G, Martellucci J, Sturiale A, Clerico G, Milito G, Marino F, et al. Consensus statement of the Italian society of colorectal surgery (SICCR): management and treatment of hemorrhoidal disease. Tech Coloproctol 2020; $24:$ 145-64.
24. Trompetto M, Clerico G, Cocorullo GF, Giordano P, Marino F, Martellucci $\mathrm{J}$, et al. Evaluation and management of hemorrhoids: Italian society of colorectal surgery (SICCR) consensus statement. Tech Coloproctol 2015; 19: $567-75$.

25. Simillis C, Thoukididou SN, Slesser AA, Rasheed S, Tan E, Tekkis PP. Systematic review and network meta-analysis comparing clinical outcomes and effectiveness of surgical treatments for haemorrhoids. Br J Surg 2015; 102: 1603-18.

26. Hollingshead JR, Phillips RK. Haemorrhoids: modern diagnosis and treatment. Postgrad Med J 2016; 92: 4-8.

27. Yilmaz I, Ozgur Karakas D, Sucullu I. Long-term Results of Hemorrhoidal Artery Ligation. Am Surg 2016; 82: 216-20.

28. Athanasiou A, Karles D, Michalinos A, Moris D, Spartalis E, Rosenberg T. Doppler-guided hemorrhoidal artery ligation and rectoanal repair modification for the treatment of grade III and grade IV hemorrhoids: one-year follow-up. Am Surg 2014; 80: 1279-80.

29. Brown SR. Haemorrhoids: an update on management. Ther Adv Chronic Dis. 2017; 8: 141-7.

30. Rakinic J, Poola VP. Hemorrhoids and fistulas: new solutions to old problems. Curr Probl Surg 2014; 51: 98-137.

31. Trowers EA, Ganga U, Rizk R, Ojo E, Hodges D. Endoscopic hemorrhoidal ligation: preliminary clinical experience. Gastrointest Endosc 1998; 48: 49-52.

32. Berkelhammer C, Moosvi SB. Retroflexed endoscopic band ligation of bleeding internal hemorrhoids. Gastrointest Endosc 2002; 55: 532-7.

33. Su MY, Chiu CT, Lin WP, Hsu CM, Chen PC. Long-term outcome and efficacy of endoscopic hemorrhoid ligation for symptomatic internal hemorrhoids. World J Gastroenterol 2011; 17: 2431-6.

34. Su MY, Chiu CT, Wu CS, Ho YP, Lien JM, Tung SY, et al. Endoscopic hemorrhoidal ligation of symptomatic internal hemorrhoids. Gastrointest Endosc 2003; 58: 871-4.

35. Schleinstein HP, Averbach M, Averbach P, Correa P, Popoutchi P, Rossini LGB. Endoscopic band ligation for the treatment of hemorrhoidal disease. Arq Gastroenterol 2019; 56: 22-7.

36. Su MY, Tung SY, Wu CS, Sheen IS, Chen PC, Chiu CT. Long-term results of endoscopic hemorrhoidal ligation: two different devices with similar results. Endoscopy 2003;35:416-20.

37. Zaher T, Ibrahim I, Ibrahim A. Endoscopic band ligation of internal haemorrhoids versus stapled haemorrhoidopexy in patients with portal hypertension. Arab J Gastroenterol 2011; 12: 11-4.

38. Fukuda A, Kajiyama T, Kishimoto H, Arakawa H, Someda H, Sakai M, et al. Colonoscopic classification of internal hemorrhoids: usefulness in endoscopic band ligation. J Gastroenterol Hepatol 2005; 20: 46-50.

39. Fukuda A, Kajiyama T, Arakawa H, Kishimoto H, Someda H, Sakai M, et al. Retroflexed endoscopic multiple band ligation of symptomatic internal hemorrhoids. Gastrointest Endosc 2004; 59: 380-4.

40. Kariya S, Nakatani M, Maruyama T, Ono Y, Ueno Y, Shimizu H, et al. Sclerotherapy for Rectal Varices by a Small-Bore Needle Puncture Through the Greater Sciatic Foramen. Cardiovasc Intervent Radiol 2018; 41: 317-22.

41. Suzuki E, Tsukigi M, Muranishi S, Sezaki H, Kakemi K. The absorption from the gut of quinine and chlorpheniramine given with various anionic agents. J Pharm Pharmacol 1972; 24: 138-44.

42. Laituri CA, Garey CL, Fraser JD, Aguayo P, Ostlie DJ, St Peter SD, et al. 15-Year experience in the treatment of rectal prolapse in children. J Pediatr Surg 2010; 45: 1607-9.

43. Akindiose C, Alatise OI, Arowolo OA, Agbakwuru AE. Evaluation of two injection sclerosants in the treatment of symptomatic haemorrhoids in Nigerians. Niger Postgrad Med J 2016; 23: 110-5.

44. An AY, Feng DY, Wang CH, Shi YY, Xiang JJ, Bai ZY, et al. Comparing the effect of An's Shaobei Injection (symbols; see text.) with Xiaozhiling Injection (symbols; see text.) in patients with internal hemorrhoids of grade I-III: a prospective cohort study. Chin J Integr Med 2014; 20: 555-60. 
45. Abe T, Hachiro Y, Kunimoto M. Combined aluminum potassium sulfate and tannic acid sclerosing therapy and anal encirclement using an elastic artificial ligament for rectal prolapse. Dis Colon Rectum 2014; 57: 653-7.

46. Miyamoto H, Hada T, Ishiyama G, Ono Y, Watanabe H. Aluminum potassium sulfate and tannic acid sclerotherapy for Goligher Grades II and III hemorrhoids: Results from a multicenter study. World J Hepatol 2016; 8: 844-9.

47. Yoshikawa K, Kawashima R, Hirose Y, Shibata K, Akasu T, Hagiwara $\mathrm{N}$, et al. Liver injury after aluminum potassium sulfate and tannic acid treatment of hemorrhoids. World J Gastroenterol 2017; 23: 5034-40.

48. Kim JH, Lee YP, Suh KW. Changes in anorectal physiology following injection sclerotherapy using aluminum potassium sulfate and tannic acid versus transanal repair in patients with symptomatic rectocele; a retrospective cohort study. BMC Surg 2018; 18: 34.

49. Jenkinson HA, Wilmas KM, Silapunt S. Sodium Tetradecyl Sulfate: A Review of Clinical Uses. Dermatol Surg 2017; 43: 1313-20.

50. Ponsky JL, Mellinger JD, Simon IB. Endoscopic retrograde hemorrhoidal sclerotherapy using $23.4 \%$ saline: a preliminary report. Gastrointest Endosc 1991; 37: 155-8.

51. Benin P, D'Amico C. Foam sclerotherapy with Fibrovein (STD) for the treatment of hemorrhoids, using a flexible endoscope. Minerva Chir 2007; 62: 235-40.

52. Alatise OI, Arigbabu OA, Lawal OO, Adesunkanmi AK, Agbakwuru AE, Ndububa DA, et al. Endoscopic hemorrhoidal sclerotherapy using $50 \%$ dextrose water: a preliminary report. Indian J Gastroenterol 2009; 28: $31-2$.

53. Tomiki Y, Ono S, Aoki J, Takahashi R, Ishiyama S, Sugimoto K, et al. Treatment of Internal Hemorrhoids by Endoscopic Sclerotherapy with Aluminum Potassium Sulfate and Tannic Acid. Diagn Ther Endosc 2015; 2015: 517690.

54. Tomiki Y, Aoki J, Motegi S, Takahashi R, Hagiwara T, Okazawa Y, et al. Effectiveness of Endoscopic Sclerotherapy with Aluminum Potassium Sulfate and Tannic Acid as a Non-Surgical Treatment for Internal Hemorrhoids. Clin Endosc 2019; 52: 581-7.

55. Muguruma N, Takayama T. Endoscopic Sclerotherapy with Aluminum Potassium Sulfate and Tannic Acid: An Effective and Less Invasive Strategy for Internal Hemorrhoids. Clin Endosc 2019; 52: 521-2.

56. Zhang T, Xu LJ, Xiang J, He Z, Peng ZY, Huang GM, et al. Cap-assisted endoscopic sclerotherapy for hemorrhoids: Methods, feasibility and efficacy. World J Gastrointest Endosc 2015; 7: 1334-40.

57. Bharucha AE, Rao SS. An update on anorectal disorders for gastroenterologists. Gastroenterology 2014; 146: 37-45.e2.

58. Kantsevoy SV, Bitner M. Nonsurgical treatment of actively bleeding internal hemorrhoids with a novel endoscopic device (with video). Gastrointest Endosc 2013; 78: 649-53.
59. Crawshaw BP, Russ AJ, Ermlich BO, Delaney CP, Champagne BJ. Prospective Case Series of a Novel Minimally Invasive Bipolar Coagulation System in the Treatment of Grade I and II Internal Hemorrhoids. Surg Innov 2016; 23: 581-5.

60. Mok SRS, Khara HS, Johal AS, Confer BD, Diehl DL. Endoscopic treatment of internal hemorrhoids by use of a bipolar system. VideoGIE 2017; 2: $290-2$.

61. Loh WL, Tan S, Ngooi MS, Ong ZK, Ngoi SS. Endoscopic monopolar coagulation of internal haemorrhoids: a surgeon's experience of the first 100 cases. Colorectal Dis 2017; 19: O86-09.

62. McLemore EC, Rai R, Siddiqui J, Basu PP, Tabbaa M, Epstein MS. Novel endoscopic delivery modality of infrared coagulation therapy for internal hemorrhoids. Surg Endosc 2012; 26: 3082-7.

63. Uberoi AS, Bhutani MS. Has the role of EUS in rectal cancer staging changed in the last decade? Endosc Ultrasound 2018; 7: 366-70.

64. Cartana ET, Gheonea DI, Cherciu IF, Streata I, Uscatu CD, Nicoli ER, et al. Assessing tumor angiogenesis in colorectal cancer by quantitative contrast-enhanced endoscopic ultrasound and molecular and immunohistochemical analysis. Endosc Ultrasound 2018; 7: 175-83.

65. Akhter A, Walker A, Heise CP, Kennedy GD, Benson ME, Pfau PR, et al. A tertiary care hospital's 10 years' experience with rectal ultrasound in early rectal cancer. Endosc Ultrasound 2018; 7: 191-5.

66. Gralnek IM, Ron-Tal Fisher O, Holub JL, Eisen GM. The role of colonoscopy in evaluating hematochezia: a population-based study in a large consortium of endoscopy practices. Gastrointest Endosc 2013; 77: 410-8.

67. Selvaggi F, Sciaudone G, Guadagni I, Pellino G. Ileal pouch-anal anastomosis after stapled haemorrhoidopexy for unrecognized ulcerative colitis. Colorectal Dis 2010; 12: e172.

68. Walega P, Scheyer M, Kenig J, Herman RM, Arnold S, Nowak M, et al. Two-center experience in the treatment of hemorrhoidal disease using Doppler-guided hemorrhoidal artery ligation: functional results after 1-year follow-up. Surg Endosc 2008; 22: 2379-83.

69. Nunes G, Marques PP, Patita M, Allen M, Gargate L. EUS-guided recanalization of complete colorectal anastomotic stenosis using a lumenapposing metal stent. Endosc Ultrasound 2019; 8: 211-2.

70. Siddiqui UD, Barth BA, Banerjee S, Bhat YM, Chauhan SS, Gottlieb KT, et al. Devices for the endoscopic treatment of hemorrhoids. Gastrointest Endosc 2014; 79: 8-14.

How to cite this article: Ma W, Guo J, Yang F, Dietrich CF, Sun S. Progress in endoscopic treatment of hemorrhoids. J Transl Intern Med 2020; 8: 237-44. 